\title{
Textual Metafunction in Persian Economic and Sports Texts
}

\author{
Dr. Foroogh Kazemi \\ Assistant Professor of Linguistics \\ Central Tehran Branch \\ Islamic Azad University, Tehran, Iran \\ f.kazemi86@yahoo.com
}

\author{
Samira Karimi \\ M. A Student of Linguistics \\ Central Tehran Branch \\ Islamic Azad University, Tehran, Iran \\ smr.karimi66@gmail.com
}

\begin{abstract}
This research is done with the purpose of comparative studying of Economic and sports press based on textual metafunction according to Halliday's functional approach. The present project is done based on analytic research and collecting data is library-based. First of all, 10 editorials are chosen of two sports and Economic presses; then 400 clauses (totally 800 clauses) randomly are analyzed. Firstly, the theme and the rheme of each clause are identified and then it is analyzed and classified according to variety of themes: simple, multiple, unmarked and marked. Data analysis of the project presented that all kinds of themes (simple, multiple, marked and unmarked) are used in sports and Economic press texts. However, they both share similarities and diversities. The difference in the mentioned texts is that the economic ones contain more multiple themes. But in sports texts simple themes are applied. Also their affinity is the usage of unmarked themes in both sports and economic genres more than the marked one. Marked themes are used less which means transition of constituents for emphasis and contrast in these contexts are seen less. Finally, choosing a theme for a clause is the representative of the authors and narrators' goals, worldviews and beliefs; that is applied in a particular style based on his chosen preferred arrangement according to his own priorities.
\end{abstract}

Keywords: Textual metafunction, Theme and rheme, Press, Economic texts, Sports texts.

\section{INTRODUCTION}

The language is alive and dynamic and is one of the vital means of describing and transferring knowledge. It is obvious that science is growing fast in the world; therefore it is crucial to describe language as the basic tool for transferring it, in different aspects by using available tools in new scientific schools. It is the time to banish the traditional language in writing science and take it into consideration as a science, which is used to convey the science. The emergence of language is due to fulfilling men's needs and its organization style according to these needs is functional and conventional. S. C. Butler believes that Halliday's Systematic Functional Grammar is derived from J. R. Firth's works, and also is affected by L. Hjelmslev, Malinowsky and Prague School. Butler denotes that Halliday has paid attention to social and cultural motives more in contrast to motives related to psychological and cognitive processes. In fact, social aspect is outstanding in Systematic Functional Grammar. In this grammar, independent grammar is not acceptable generally, because this theory is highly focused on meaning; and syntax pattern is known as the only mechanism for recognizing the meaning, meaning a means to target (Butler, 697:2003).

Language in Halliday's view is a tangled network of complex semiotic system that consists of five levels top-down textural, semantic, lexico-grammar, phonetic and phonological. In this model, the speaker forms the meaning in texture by selecting available choices at each level. Halliday focuses on semantics, by putting emphasis on absence of any bound between grammar and meaning. Now it is obvious why this theory is called Systematic Functional Grammar. This theory is functional, for it's based on the meaning; it is a grammar, therefore the outcome is semantic interpretation of language forms or the very grammar. And finally it is systematic because it's a tangled network of grammar and semantic choices (Halliday and Matthiessen, 25:2004).

This project is an attempt for comparing press texts in the format of Halliday's systematic functional theory from the textual metafunctional perspective. In this survey, we analyze kinds of theme, diversity, distribution and occurrence frequency in press texts, especially, 'sport news' and 'the world of economy'. The main issue raised in this article is how text structures are used in terms of the order of the sentences structure, especially the themes in mentioned press texts, from the perspective of 


\section{Dr. Foroogh Kazemi \& Samira Karimi}

textual metafunctional and its role in the frame of Halliday's systematic functional theory. This research is looking for the response to the questions such as which kinds of themes are seen in economical and sports texts and how the usage frequency of simple, multiple, marked and unmarked themes are in these texts. It is good to mention that the process quality and the writing fashion of press texts are considerable for readers in improving comprehension and the method of conveying the meaning. A tool is introduced by Halliday's Systematic Functional Grammar that is able to present the linguistic and sematic description of language. The importance of this project is due to its methods of using the tools in composition and processing of press texts by Halliday's Systematic Functional Grammar. This project takes into consideration the role and textual function of themes genres. The order of text constituents and the relation between theme and rheme lead to text cohesion and text development which resulted in an explicit, fluent, clear and apprehensible text.

This project is done based on analytic research and collecting data is library-based. Data versions in this project, clauses and the sentences of two popular sports news and the world of economy texts are from two distinct domain of press composition. In this research, for better and more precise comparison of these two publications, the editor's 20 editorials of these journals which are synchronized with compositions strategies of the two domains are selected by random sampling (each publication's share is 10 editorials), in general 800 clauses of these two sports and economic press are analyzed in terms of the type and the function scale of themes. According to the defined number of the survey, the 800 clauses are considerable in terms of quantity and a brief analysis of these texts can be achieved by its results.

\section{LiteratURE REVIEW}

Gomez (1994) analyzed the theme function in BBC news reports. In this analysis, he found 486 themes that all of them were applied in news clauses. In his paper, he separated the marked theme from the unmarked one and after studying the multiple themes, he concludes that the sequence of textual + practical themes is more common than the other sequences. Fries (1995) studied four kinds of texts: obituary, introduction of concerts programs, story, explanation and interpretation. He has analyzed totally 367 clauses and resulted in the more usage of simple theme in the whole context than multiple one. In story prose, the simple theme is applied more than the multiple themes. The sequence of textual + practical themes is the common in whole context and in the entire text textual theme is more used than interpersonal ones.

Ghadessy (1995) has approved Fries's theory about the correlation between theme and text formation (style) and believes that theme selection brings about text development and the text writing style is affected by it. Lock (1996) has concluded based on his studies that in Italian language, the configuration of structures arrangement's criterion in marked and unmarked theme recognition, and based on occurrence frequency, is not precise. In Italian speech, the occurrence frequency of object is more possible in theme of the sentence; however in Italian writing the occurrence frequency of subject is feasible in theme position. Karin (2006) in his research titled as 'Textuality in the text: word analysis of a news article...' has stated Halliday and Hasans' (1976) definition of text. These two linguists have known the text as a valid written or spoken article and believe that cohesion and textuality in the text is a factor to give a text the meaning, while it is also one of the third metafunction creators of meaning. In this project, reference principles, alternation, omission, relevance and coherence of words are introduced and their role in formation of overall meaning is defined clearly. Wang (2007) in a paper, titled as 'theme and rheme in organization of the text: effective role of theme and rheme in academic writing teaching', based on the relation of theme and rheme in Halliday's perspective in academic texts, has remarked that the analysis of theme and rheme in texts teaches the students using the same analysis in their writing and in conclusion, the cohesion of their texts will be increased. He has classified the common mistakes in using theme and rheme.

Arab Zoozani and Pahlavan Nezhad (2013), after analyzing the frequency and the theme type of English books in high school level in Iran in terms of textual metafunctionin Halliday's Systematic Functional Grammar theory concluded that the number and types of clauses in reviewed texts are not following a specific rule or procedure and unexpectedly the frequency ratio of clauses with marked themes, that can the degree of the text difficulty, from lowest level to highest one, to the clauses with marked themes didn't improved and even it has been more in the first level. Fahimnia (2009) in his Ph.D. thesis has analyzed the metafunctional theme in terms of Halliday's approach and studied the primary school students' Persian books. According to his findings, the categories in Halliday's 
systematic grammar are adaptable. Kazemi (2012) in her Ph.D. dissertation has investigated the theme and rheme in six books and nineteen articles of Persian and English scientific texts. She simultaneously analyzed theme-rheme structure besides existing marked themes in Persian and English languages and showed their comparison and contrast aspects.

\section{Textual Metafunction}

In Halliday and Matthiessen's Systematic Functional Grammar (2004), due to excellence oriented philosophy, language and language system comes from meaning and the meaning is very common that is considered in three levels as follows: texture or transcultural meaning, texture or cultural meaning, texture or situational and spontaneous meaning. In the latest one (texture or situational and spontaneous meaning) that is the same conversation condition, three main elements as representative roles and functions of language is as follows: mode of discourse or media, participants of discourse, tenor of discourse. These three elements are shown in words and grammar system by three levels of meaning or meaning - grammar metafunction: textual metafunction, interpersonal metafunction, ideational (experiential) metafunction. The fourth meaning level is logical metafunction. In ideational level, the method of language function in representation of human experiences of inside and outside world is analyzed.

In interpersonal metafunction, the role of language in human's communication and interactions and the exchange of meaning between speaker and listener are noticed. In textual metafunction, any clauses of speeches or any sentences of writings is considered systematic, transposition or being at the beginning or the end of elements and language structure are meaningful and vital and they are ordered and analyzed. In logical metafunction, the logical - semantic relation between clauses or sentences in a written or spoken text is concerned. So, as this research is about textual metafunction, the available roles in metafunction consisting themes and its kinds are included in the following:

\subsection{Simple and Multiple Themes}

This type of themes is consisted of two types: a) if the theme is made of a structural element or a unit, is simple. In this case, the theme contains one structure or group (such as nouns, adverbs or prepositional groups). b) Whenever the theme is made of at least two or more groups or phrases, in a way that these elements make a single structural element, again it is called simple. This common type of theme is the complex of two or more groups or phrases which is usually made by prepositions and conjunctions and leads into multiple group or phrase or is seen as apposition (Halliday and Matthiessen, 68:2004). Sometimes in theme's place, some elements are seen next to each other that contain meaning levels of ideational, interpersonal or textual. Almost, one or two language elements are appeared in this place, in other words, if the first constituent of the clause theme is an added circumstantial factor or the main verb (process itself) or the participants, the theme is simple. But if elements of textual and interpersonal metafunction, (equals to non-experiential), comes before it, it is multiple theme (Halliday and Matthiessen, 2004).

\subsection{Marked and Unmarked Themes}

In linguistics, the unmarked term is used as its common definition but the marked term is not. One of the important points in defining the concept of being marked is the poor application of language elements. Depending on the arrangement of elements of each aspect, the more occurrence and anonymous condition in theme place, the theme can be divided into two groups, marked and unmarked. By analyzing the themes in clauses and different aspects, we can view that marked and unmarked themes are various and each one is different from the other one. Therefore, in Systematic Functional Grammar, being in markedness category is proportional from a structure to another one, and the generalization is not feasible. For analyzing this category we must define markedness in any structure independently; namely defining unmarked theme in its own special aspect (Kazemi, 2015).

\section{Data Analysis}

In this part we analyze textual metafunction in sports press and economical press texts. First of all, kinds of themes (simple, multiple, marked, unmarked) of the corpus are presented in the format of charts, and also in the following there are charts that diversity is shown as well as distribution and occurrence frequency of each kind of themes in the whole case (800 studied clauses). 


\section{Dr. Foroogh Kazemi \& Samira Karimi}

Table4.1. Simple theme with one structure/group (noun) in economic and sports press texts

\begin{tabular}{|c|c|c|c|}
\hline row & Text type & Simple theme & rheme \\
\hline \multirow{2}{*}{1} & \multirow{3}{*}{ economic } & $\begin{array}{c}\text { motevaliyâne siyâsathâye kalâne } \\
\text { Peqtesâdi }\end{array}$ & hanuz negarâne tavarom hastand \\
\cline { 3 - 4 } & & Custodians of macroeconomic policy & are still concerned about inflation. \\
\hline \multirow{2}{*}{2} & \multirow{3}{*}{ sport } & Pamaliyâte teroristi & $\begin{array}{c}\text { hamzamân bâ Pin bâzi dar xiyâbânhâye } \\
\text { pâris šoru šod }\end{array}$ \\
\cline { 3 - 4 } & & Terrorist operation & $\begin{array}{c}\text { began simultaneously with this game in } \\
\text { Paris streets }\end{array}$ \\
\cline { 3 - 4 } & & &
\end{tabular}

In the above table, the order of cells is as follows: simple theme and rheme. In the first clause, custodians of macroeconomic policy is as a noun and subject, and the rest of clause are still concerned about inflation is considered as rheme.

Table4.2. Simple theme with multiple structure/group in economic and sports press texts

\begin{tabular}{|c|c|c|c|}
\hline row & Text type & Simple theme & rheme \\
\hline \multirow[b]{2}{*}{1} & \multirow[b]{2}{*}{ economic } & xânevârhâ va hatâ bongâhhâye ?eqtesâdi & $\begin{array}{l}\text { pasandâzhâye xodrâ ravâneye bâzârhāye } \\
\text { digari hamčon bâzâre maskan konand }\end{array}$ \\
\hline & & Families and even businesses & $\begin{array}{l}\text { should invest their savings in other } \\
\text { markets such as housing market. }\end{array}$ \\
\hline \multirow[t]{2}{*}{2} & \multirow[t]{2}{*}{ sport } & $\begin{array}{c}\text { Golleye marāme pahlevāni va noGteye } \\
\text { oje farhange pahlevāni }\end{array}$ & sahâdat Past \\
\hline & & $\begin{array}{c}\text { The peak of athletic creed and the climax } \\
\text { of athletic culture }\end{array}$ & is martyrdom. \\
\hline
\end{tabular}

In the above mentioned table, as it is seen, themes create multiple groups or terms by conjunction group or links, in the second cell of the aforesaid table, the construction of two noun groups the peak of athletic creed and the climax of athletic culture create a multiple noun group that are formed by conjunction 'and'.

Table4.3. Multiple theme (textual theme + ideational theme) in economic and sports presstexts

\begin{tabular}{|c|c|c|c|c|}
\hline \multicolumn{4}{|c|}{ Multiple theme } & \multirow[t]{2}{*}{ rheme } \\
\hline Row & Text type & textual & Ideational & \\
\hline \multirow[t]{2}{*}{1} & \multirow[t]{2}{*}{ economic } & va & dolat & $\begin{array}{c}\text { bâyad dar râstâye taGviyate naGdinegiye bâzâre } \\
\text { sahâm siyâsate ?enGebâziye xod râ motavaqef } \\
\text { konad }\end{array}$ \\
\hline & & and & government & $\begin{array}{c}\text { needs to stop its contractionary monetary policy } \\
\text { stock in order to boost market liquidity. }\end{array}$ \\
\hline \multirow[t]{2}{*}{2} & \multirow[t]{2}{*}{ sport } & garče & $\begin{array}{l}\text { bâzihâye Pâti bâ } \\
\text { Pomân va hend }\end{array}$ & kenoruze 95 Panjâm mišavad \\
\hline & & Although & $\begin{array}{l}\text { Future games with } \\
\text { Oman and India }\end{array}$ & that takes palce in Nowrooz 95 \\
\hline
\end{tabular}

In the aforesaid table, in both clauses textual theme became before the main theme, the same ideational one. By existence of textual metafunction before ideational element the theme will be multiple. In the second clause the textual theme is although and the ideational theme is future games with Oman and Kuwait. The sequence of themes is textual and then ideational theme.

Table4.4. Multiple theme (textual theme +interpersonal +ideational theme) in economic and sports press texts

\begin{tabular}{|c|c|c|c|c|c|}
\hline \multicolumn{9}{|c|}{ Multiple theme } & \multirow{2}{*}{ rheme } \\
\hline Row & Text type & textual & interpersonal & ideational & \\
\hline 1 & economic & va & Pehtemâlan & dar Pâyandeye nazdik & Pin ravand Pedâme xâhad dâšt \\
\cline { 3 - 6 } & & and & probably & in near future & this trend will be continued. \\
\hline 2 & \multirow{2}{*}{ sport } & vali & xošbaxtâne & mohâjemân & $\begin{array}{c}\text { vârede varzešgâhe Postâd do } \\
\text { ferâns našodand }\end{array}$ \\
\cline { 4 - 5 } & & but & fortunately & the strikers & $\begin{array}{c}\text { didn't enter the Stade de France } \\
\text { stadium. }\end{array}$ \\
\cline { 3 - 5 } & & & & & \\
\hline
\end{tabular}

In the above table, in the first cell both textual and interpersonal themes are before the main theme. The textual theme is but, and the interpersonal theme is fortunately. The interpersonal theme usually shows the speaker's view about the predicate. So, the existed frequency is textual and then interpersonal which is common but its opposite is not. Namely textual comes first and then the interpersonal themes. 
Textual Metafunction in Persian Economic and Sports Texts

Table4.5. Multiple theme (interpersonal +ideational theme) in economic and sports press texts

\begin{tabular}{|c|c|c|c|c|}
\hline \multicolumn{2}{|c|}{ Multiple theme } & \multicolumn{2}{c|}{ rheme } \\
\hline Row & Text type & interpersonal & ideational & \\
\hline \multirow{2}{*}{1} & economic & bedune tardid & $\begin{array}{c}\text { šekaste mozâkerâte } \\
\text { haste?i }\end{array}$ & $\begin{array}{c}\text { čašm?andâze dastyâbi be tavarome } \\
\text { takraqami râ hadde Paqal tâ sâle 1397 } \\
\text { tire vo târ mikard }\end{array}$ \\
\cline { 3 - 5 } & \multirow{2}{*}{ sport } & $\begin{array}{c}\text { without } \\
\text { hesitation }\end{array}$ & $\begin{array}{c}\text { the failure of nuclear } \\
\text { talks }\end{array}$ & $\begin{array}{c}\text { blackened the outlook of achieving } \\
\text { single-digit inflation at least till 1397. }\end{array}$ \\
\cline { 3 - 5 } & Apparently & $\begin{array}{c}\text { kesâdie bâzârhâ va } \\
\text { moškele foruš }\end{array}$ & $\begin{array}{c}\text { čenân farâgir va xesâratbâr bude } \\
\text { sale problem }\end{array}$ & was so pervasive and detrimental. \\
\hline
\end{tabular}

As it is seen in the table 4.5 the theme is multiple and consisted of construction of interpersonal and ideational themes. In the first clause the interpersonal theme is without hesitation which conveys the speaker's viewpoint and functions as an interaction between the speaker and the listener, or the writer and the reader. And the failure of nuclear talks is as the main theme; Blackened the outlook of achieving single-digit inflation at least till 1397 is the rest of the sentence which is as the rheme of the clause.

Table4.6. Unmarked themes in economic and sports press

\begin{tabular}{|c|c|c|c|}
\hline & & & clause \\
\hline Row & Text type & Theme & Rheme \\
\hline \multirow[b]{2}{*}{1} & \multirow[b]{2}{*}{ economic } & hadafe Pin maqâle & $\begin{array}{l}\text { Baresiye siâsathâye kalâne puli va mâliye jâri va Penteqâdhâye } \\
\text { matrah šode dar morede ?ânhâ Paz didgâhe nazari va tajrobi ?ast }\end{array}$ \\
\hline & & $\begin{array}{l}\text { The purpose of } \\
\text { this article }\end{array}$ & $\begin{array}{c}\text { is the analysis of macro monetary and fiscal policies and } \\
\text { considered criticism about them by theoretical and practical } \\
\text { approach. }\end{array}$ \\
\hline \multirow[t]{2}{*}{2} & \multirow[t]{2}{*}{ sport } & torkamanestân & $\begin{array}{l}\text { harife Pemruze time melli dar rotbeye } 121 \text { rankinge fifâ Garâr } \\
\text { dârad }\end{array}$ \\
\hline & & Turkmenistan & $\begin{array}{c}\text { today's opponent of national team is placed as } 121 \text { in FIFA } \\
\text { ranking. }\end{array}$ \\
\hline
\end{tabular}

In the table 4.6, Turkmenistan comes as the theme and subject of the clause, so due to following normal base, it is placed in unmarkedness category. The 'Today's opponent of national team is placed as 121 in FIFA ranking' is as the rheme of the clause.

Table4.7. Marked themes in economic and sports press

\begin{tabular}{|c|c|c|c|c|}
\hline Row & Text type & clause & Category & $\begin{array}{c}\text { functi } \\
\text { on } \\
\end{array}$ \\
\hline \multirow[t]{2}{*}{1} & \multirow[t]{2}{*}{ economic } & $\begin{array}{c}\text { teye doreye } 1390 \text { tâ } 1394 \text { \# nerxe Parz dar kânune Pasliye } \\
\text { tahavolâte tavaromi Garâr gereft }\end{array}$ & \multirow[t]{2}{*}{ Adverbs } & \multirow{2}{*}{$\begin{array}{c}\text { Adjun } \\
\text { ct }\end{array}$} \\
\hline & & $\begin{array}{c}\text { During } 1390 \text { to } 1394 \text { \# the exchange rate was the main focus of } \\
\text { inflationary developments. }\end{array}$ & & \\
\hline \multirow[t]{2}{*}{2} & \multirow[t]{2}{*}{ sport } & $\begin{array}{c}\text { teye ruzhâye gozašte \# masâ?ebe besiyâri dar râhe daryâfte } \\
\text { vizâye bâzikonâne time melli voǰud dâšt }\end{array}$ & \multirow[t]{2}{*}{ Adverbs } & \multirow{2}{*}{$\begin{array}{c}\text { Adjun } \\
\text { ct }\end{array}$} \\
\hline & & $\begin{array}{c}\text { During the past days \# there were lots of tragedies in order to } \\
\text { get the national team's visa. }\end{array}$ & & \\
\hline
\end{tabular}

In the above table, there are marked themes. For instance, in the second clause the adverb during the past days is as the subject or theme of the clause, and the subject of the clause, lots of tragedies is located in rheme, hence this clause is called marked due to the transposition.

Table4.8. Types and frequency percentage of simple and multiple themes divided in economical and sports press texts

\begin{tabular}{|c|c|c|c|c|c|c|}
\hline \multirow{2}{*}{ Row } & \multicolumn{2}{|c|}{ Types of themes } & \multicolumn{2}{c|}{ Economical press texts } & \multicolumn{2}{c|}{ Sports press texts } \\
\cline { 3 - 6 } & & Frequency & Percentage & Frequency & Percentage \\
\hline 1 & \multirow{2}{*}{$\begin{array}{c}\text { Simple } \\
\text { theme }\end{array}$} & Simple theme & 150 & $37.5 \%$ & 192 & $48 \%$ \\
\cline { 3 - 7 } & & $\begin{array}{c}\text { Simple theme with one } \\
\text { complex structure/ group }\end{array}$ & 18 & $4.5 \%$ & 10 & $2.5 \%$ \\
\hline
\end{tabular}


Dr. Foroogh Kazemi \& Samira Karimi

\begin{tabular}{|c|c|c|c|c|c|c|}
\hline 3 & \multirow{3}{*}{$\begin{array}{l}\text { Multiple } \\
\text { theme }\end{array}$} & $\begin{array}{l}\text { multiple theme (textual theme } \\
\text { + ideational theme) }\end{array}$ & 219 & $54.75 \%$ & 184 & $46 \%$ \\
\hline 4 & & $\begin{array}{l}\text { multiple theme (textual theme } \\
\text { +interpersonal +ideational } \\
\text { theme) }\end{array}$ & 6 & $1.5 \%$ & 9 & $2.25 \%$ \\
\hline 5 & & $\begin{array}{l}\text { multiple theme (interpersonal } \\
\text { +ideational theme) }\end{array}$ & 7 & $1.75 \%$ & 5 & $1.25 \%$ \\
\hline \multicolumn{3}{|c|}{ Number of clauses in each cell } & 400 & $100 \%$ & 400 & $100 \%$ \\
\hline \multicolumn{3}{|c|}{ Total studied clauses } & \multicolumn{4}{|c|}{800} \\
\hline
\end{tabular}

Table4.9. Types and frequency percentage of unmarked and marked themes divided in economical and sports press texts

\begin{tabular}{|c|c|c|c|c|c|}
\hline \multirow{2}{*}{$\begin{array}{c}\text { Ro } \\
\mathbf{w}\end{array}$} & Types of themes & Economical press texts & \multicolumn{2}{c|}{ Sports press texts } \\
\cline { 3 - 6 } & & Frequency & Percentage & Frequency & Percentage \\
\hline 1 & Unmarked theme & 244 & $61 \%$ & 229 & $57.25 \%$ \\
\hline 2 & Marked theme & 156 & $39 \%$ & 171 & $42.75 \%$ \\
\hline \multicolumn{2}{|c|}{800} \\
\hline \multicolumn{2}{|c|}{ Number of clauses in each cell } & 400 & $100 \%$ & 400 & $100 \%$ \\
\hline
\end{tabular}

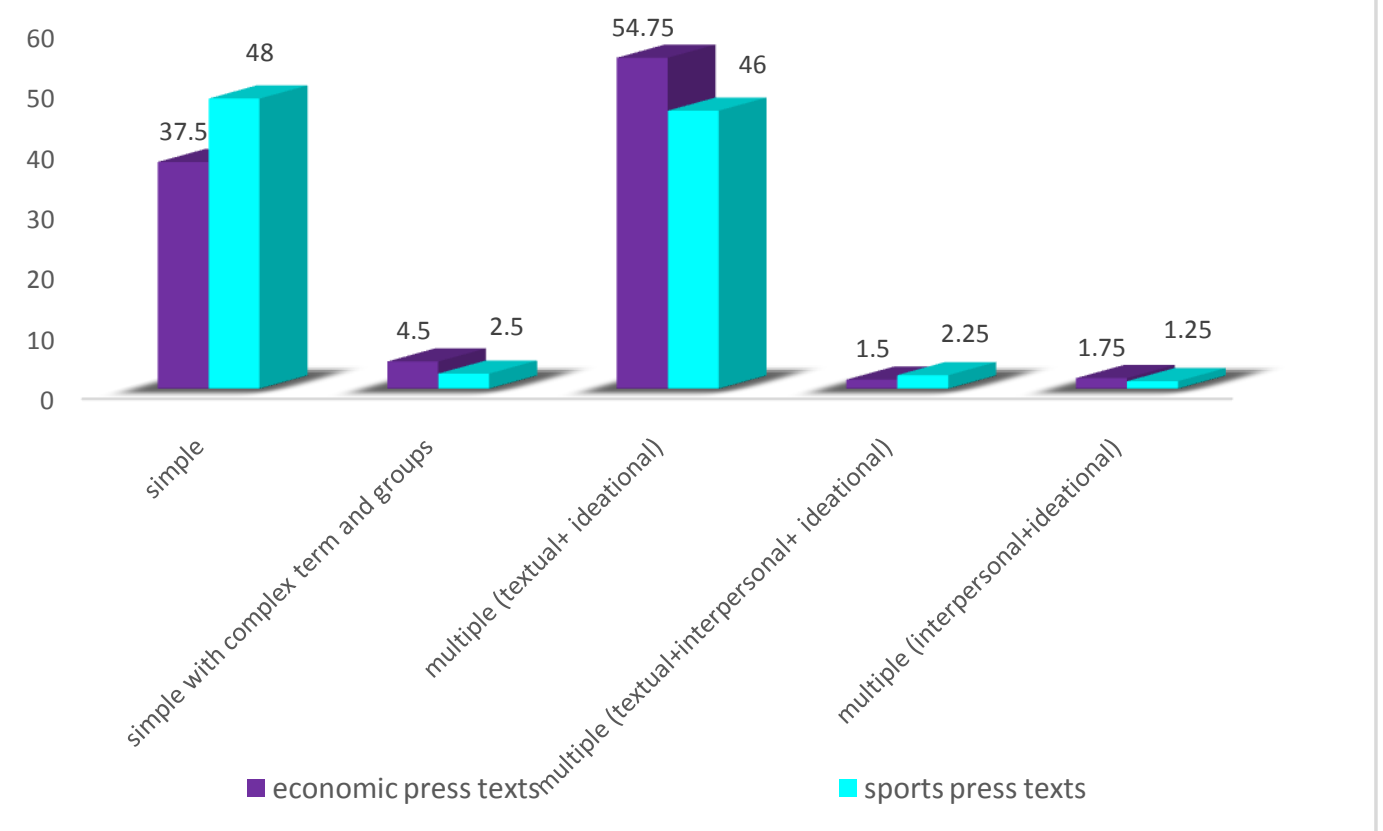

Figure1. Types of simple and multiple themes in economic and sports press texts

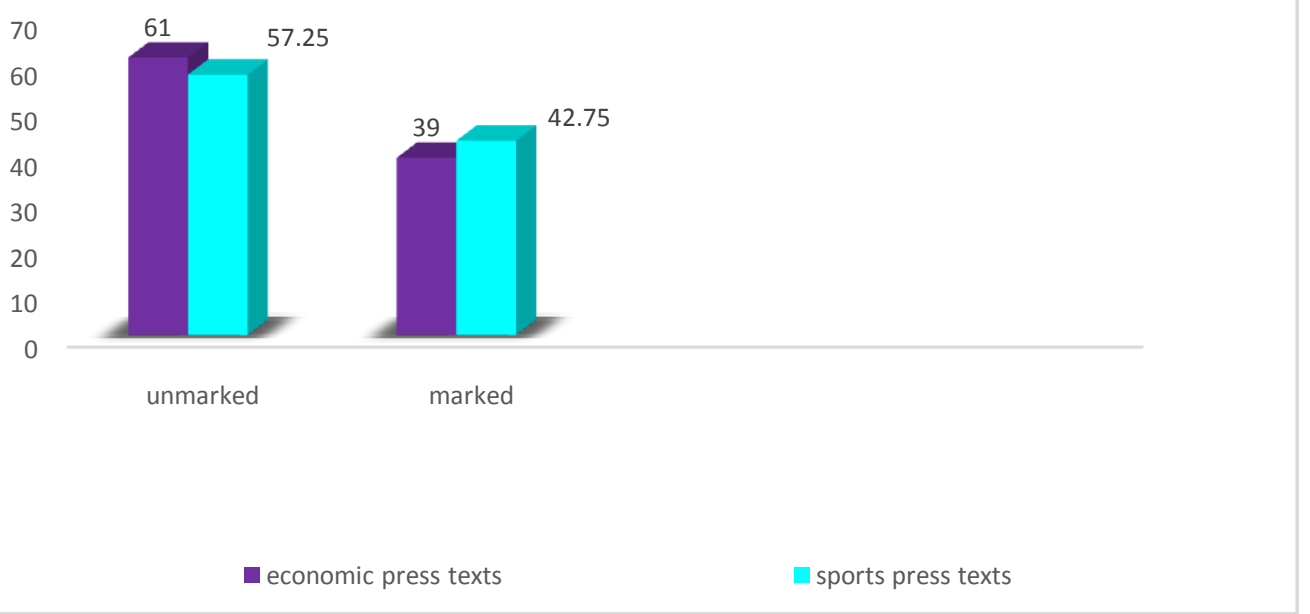

Figure2. Types of marked and unmarked themes in economic and sports press texts 


\section{CONCluSion}

This research has defined the types and occurrence frequency of themes in the studied case by accomplished analysis, and has also done a comparative and contrast study of the press texts. The findings of the research present that in economic texts among studied clauses, the simple theme indicates $37.5 \%$ and the simple theme with complex term or groups shows $4.5 \%$, and also multiple theme ( textual theme + ideational theme) signifies $54.75 \%$; multiple theme (textual theme + interpersonal theme + ideational theme) shows $1.5 \%$; multiple theme (interpersonal theme+ ideational theme) indicates $1.75 \%$ and likewise, unmarked theme has been allocated $61 \%$ and marked theme about 39\%. In sports texts among 400 studied clauses, the simple theme indicates $48 \%$ and the simple theme with complex term or groups shows $3.5 \%$, and also multiple theme (textual theme + ideational theme) signifies $46 \%$; multiple theme (textual theme + interpersonal theme + ideational theme) shows $2.25 \%$; multiple theme (interpersonal theme+ ideational theme) indicates $1.25 \%$ and likewise, unmarked theme has been allocated $57.25 \%$ and marked theme about $42.75 \%$.

According to the comparison between types of simple/multiple theme and marked/unmarked theme, their diversity and affinity have been found out. The difference of two texts is regarded to the first category simple/multiple theme. So, in economic texts, multiple themes are used more. But in sports texts, simple ones are applied. Their affinity is regarded to the second category marked and unmarked themes, in other words markedness. In both texts unmarked themes are used more and marked ones shows less usage; which means that structure transposition for emphasis or irony is occurred less that shows according to textual metafunction analysis we can find out and study distinct authors' writing approaches.

This conclusion also proves that clauses and sentences can be stated in different ways which has a unique and distinct effect on the addressee, especially on his comprehension. Textual metafunction is as a tool for recognizing language varieties and writing styles. The accurate comprehension of any texts needs exact transferring of content to listener or reader and it is because of the vitality of the structure and mode of expression. So in this regard textual metafunction which is the same mode of expression declares specific formal tools in this way. One of the applications of this kind of research that can be indicated is its application in stylistics and text recognition.

\section{REFERENCES}

[1] Arab Zouzani, M. A. \& Pahlevan Nejad, M. R. (2014), "The Study of Marked and Unmarked Theme in Iranian High School English Text Books based on Halliday's Systemic Functional Grammar", Language related research, vol.6, No.3 (Tome 24), July, August \& September 2015.

[2] Butler, S. C. (2003), Structure and Function: A Guide to Three Major Structural - Functional Theories, Part 1: Approaches to the simplex Clause, Amsterdam/Philadelphia: John Benjamins Publishing. Co.

[3] Crane, A. P. (2006), "Texture in Text: A Discourse Analysis of a News Article Using Halliday and Hasan's Model of Cohesion”, Journal of School of Foreign Languages, Pp. 1-131.

[4] Fahimnia, F. (2009), Analysis of the metafunctional theme in terms of Halliday's approach in primary school students' writings and Persian books, Ph.D. thesis, Humanities and Cultural studies institute.

[5] Fries, P. H. (1995), Language Communication and Social Meaning, Washington Dc: Georgetown University Press, pp. 336-352.

[6] Ghadessy, M. (1995), Thematic Development in English Text, London: Printer.

[7] Gomez, M. (1994), "The Relevance of Theme in the Textual Organization", BBC News Reports. WORLD. Vol. 45 (3), pp. 293-305.

[8] Halliday, M. A. K. \& Hassan, R. (1976), Cohesion in English, London: Longman.

[9] Halliday, M. A. K. \& Matthiessen, C. (2004),An Introduction to Functional Grammar, New York: Oxford University Press Inc.

[10] Kazemi, F. (2012), The theme and rheme in scientific Persian and English texts according to Halliday's Functional Systematic Grammar theory, Ph.D. dissertation, Islamic Azad University, science and research branch, Tehran. 
[11] Kazemi, F. (2015), "Theme Markedness in Persian and English Medical Text; A SystemicFunctional Approach", Theory and Practice in Language Studies, Vol. 5, No. 11, pp. 24162425.

[12] Lock, G. (1996), Functional English Grammar: An Introduction for Second Language Teachers, Cambridge University Press.

[13] Wang, L. (2007), "Theme and Rheme in the Thematic Organization of Text: Implications for Teaching Academic Writing", In Asian EFL. Volume 9. Issue 1.

\section{AUTHORS' BIOGRAPHY}

Foroogh Kazemi is assistant professor of linguistics department in Central Tehran Branch, Islamic Azad University in Iran. She has taught linguistics, Persian and English at Central Tehran Branch, Imam Khomeini International University and Science and Research branch. Dr. Kazemi has published many articles in linguistics and has been advisor, reader and referee of many linguistic MA theses and judge of articles in journal of linguistics. Her areas of interest are functional linguistics, sociolinguistics, typology and discourse analysis. She is the head of linguistics department and a member of research council in Central Tehran Branch, Islamic Azad University.

Samira Karimi was born in Hamedan in 1987. She is BS of English Language and literature at Hamedan Branch, Islamic Azad University, in 2010. She is now, MA student of linguistics, at Central Tehran Branch, Islamic Azad University. 